\title{
NGHIÊN CỨU CHẨN ĐOÁN VIÊM PHÚC MAC RUỘT THỪA TẠI MộT SỐ BỆNH VIỆN ĐA KHOA TỈNH MIỀn NÚI PHÍA BẮC
}

\section{TÓM TẮT}

Mục tiêu: Nghiên cứu chẩn đoán viêm phúc mạc ruôt thừa tai môt số bênh viên đa khoa tỉnh miền núi phía Bắc. Đối tượng và phướng pháp: Tiến cứu mô tả tiến hành trên 468 trường hợp bệnh nhân đước chẩn đoán VPMRT được điều trị bằng phẫu thuật nội soi từ 01/01/2015 đến 31/9/2017 tại các bênh viền đa khoa tỉnh miền núi phía Bắc. Kết quả và kết luận: Bênh chủ yếu găp trong độ tuổi lao động 19-60; tị lệ nam/nữ tương đương; thời gian từ khi đau tới khi vào viện đa phần > 24 giờ; Tỉ lệ gặp RT vị trí bất thường là $13,2 \%$; Các nguyên nhân gây VPMRT gặp phải bao gồm trình đô hoc vấn thấp, trẻ em dưới 5 tuổi, người già $\geq 60$ tuổi, phụ nữ có thai, phẫu thuật ổ bụng từ trước; đa số các bệnh nhân có sốt chiếm $62,4 \%$; tất cả các bệnh nhân đều có triệu chứng cơ năng đau bunng, một số bệnh nhân gặp tình trạng nôn, buồn nồn, rối loạn đại tiện; tất cả các bệnh nhân đều có triệu chứng đaù và phản ứng thành bụng trên lâm sàng, triệu chứng hay gặp khác là bụng chướng và cảm ứng phúc mạc; đa số các bệnh nhân có tăng $\mathrm{BCDNTT}$ chiếm $79,3 \%$; tỉ lê làm xét nghiêm $\mathrm{CRP}$ là $10,2 \%$ trong đó tỉ lệ CRP tăng chiếm $93,75 \%$; có 112 (23,9\%) bệnh nhân được lấy mẫu cây vi khuẩn; tỉ lê phát hiện vi khuẩn $E$. Coli là $73,2 \%$; Klebsiella là 5,4\%; Pseudomonas 4,5\%; Enterococus là 1,8\%; loại khác $9,8 \%$.

Từ khóa: Viêm phúc mạc ruột thừa (VPMRT)

\section{SUMMARY}

\section{DIAGNOSIS OF APPENDICEAL PERITONITIS IN NORTHERN MOUNTAINOUS HOSPITALS}

Objective: To study the diagnosis of appendiceal peritonitis in some general hospitals in the Northern mountainous province. Subjects and methods: Prospective descriptive study conducted on 468 cases of patients diagnosed with appendiceal peritonitis treated by laparoscopic surgery from January 1, 2015 to September 31, 2017 at northern mountainous hospital. Results and conclusion: The disease was mainly seen in the working age group 19-60; male/female ratio was equal; time from pain to surgery was mostly > 24 hours; The rate of abnormal position apendix was 13.2\%; The causes of appendiceal peritonitis included low education level, children under 5 years old, elderly people $\geq 60$ years

\footnotetext{
*Bênhh viện Đa khoa Chiêm Hóa

**Bênh viên Hữu Nghi Viêt Đức

Chiu trách nhiệm chính: Nguyê̂n Hưng Đạo

Email: bienpham1102@gmail.com

Ngày nhân bài: 21/7/2021

Ngày phản biên khoa họ: 10/8/2021

Ngày duyệt bài: 25/8/2021
}

\author{
Nguyễn Hưng Đạo*, Trịnh Hồng Sơn**
}

old, pregnant women, previous abdominal surgery; most of the patients had fever accounted for $62.4 \%$; all patients have symptoms of abdominal pain, some patients have vomiting, nausea, bowel disorders; Al patients had clinical symptoms of abdominal pain and reaction, other common symptoms were abdominal distension and peritoneal tenderness; the majority of patients had an increase in neutrophil, accounting for $79.3 \%$; the rate of doing CRP test is $10.2 \%$, of which the rate of CRP increase accounts for $93,75 \% ; 112$ (23.9\%) patient's sample were taken for bacterial cultures; the percentage of samples detecting bacteria accounted for 23,9\%; E. Coli detection rate was 73,2\%; Klebsiella5,4\%; Pseudomonas4,5\%; Enterococus1,8\%; other 9,8\%.

Key words: Appendiceal peritonitis (AP)

\section{I. ĐăT VẤN ĐỀ}

Viêm ruột thừa (VRT) là một trong những cấp cứu ngoại khoa gặp hàng đâu. Viêm phúc mạc (VPM) do viêm ruột thừa (VRT) là một biến chứng nặng hay gặp trong thực hành lâm sàng. Việc phẫu thuật và điêu trị bệnh nhân viêm phúc mạc ruột thừa (VPMRT) sẽ tốn kém, khó khăn và để lại nhiều di chứng so với giai đoạn sớm. Các tỉnh miền núi phía Bắc với địa bàn rộng, có nhiêu dân tộc khác nhau sinh sông, kinh tế nói chung còn nghèo, cùng với phong tục tập quán lạc hậu, giao thông đi lại không thuận lợi.... Tình hình y tế còn nhiều bất cập: thiếu nhân lực cũng như trang thiết bi dẫn đến khó khăn trong chẩn đoán VPMRT. Việc chẩn đoán sớm VPMRT giúp đưa ra chỉ định mổ phù hợp đặc biệt với sự tiến bộ của y học trong ứng dụng phẫu thuật nội soi vào VPMRT. Do vậy việc phát hiện và chẩn đoán sớm VPMRT rất quan trọng trong việc giảm thiểu biến chứng và tỉ lệ tử vong của bệnh nhân.

\section{II. ĐỐI TƯỢNG VÀ PHƯƠNG PHÁP NGHIÊN CỨU}

2.1. Đối tượng nghiên cứu. Tất cả các bệnh nhân được chẩn đoán VPMRT (VFMTT, VFMKT, Áp xe RT) được điều trị bằng phầu thuật nội soi từ 01/01/2015 đến 31/9/2017 tại các bệnh viện đa khoa tỉnh miền núi phía Bắc.

\section{a. Tiêu chuẩn chọn bệnh nhân.}

- Gồm tất cả các bệnh nhân được chẩn đoán là VPM do VRT, các bệnh nhân này có triệu chứng lâm sàng và cận lẩm sàng của một VRT có biến chứng VPM được điêuu trị bằng PTNS tại 8 bênh viện đa khoa tuyến tỉnh là: Bắc Giang, Bắc Kạn, Cao Bằng, Điện Biên, Hà Giang, Hòa Bình, Sơn La, Tuyên Quang. 
- Các bệnh nhân này có chẩn đoán trong mổ và sau mổ đều là VPM do VRT.

- Những bệnh nhân này có hồ sơ đây đủ các dữ liệu chẩn đoán trước mổ, cách thức phẫu thuật, kết quả theo dõi và đánh giá kết quả sau mổ.

- Không có tiền sử mổ cũ từ hai lần trở lên hoặc bệnh nhân có đường mổ cả đường trắng giữa trên và dưới rốn

- Không có chống chỉ định trong phẫu thuật nội soi.

- Sau khi đã giải thích cho bệnh nhân hay người đại diện bệnh nhân về lợi ích và nguy cơ của phương pháp phẫu thuật nội soi, được họ đồng ý để tiến hành nghiên cứu.

b. Tiêu chuẩn loai trừ

- Không Không ghi chép đầy đủ các mục trong bệnh án mẫu nghiên cứu.

- Đám quánh ruột thừa

- Chẩn đoán sau mổ là VPM do các nguyên nhân khác.

\subsection{Phương pháp nghiên cứu}

a. Thiết kế nghiên cứu. Nghiên cứu mô tả, tiến cứu. Bệnh nhân được phẫu thuật theo một quy trình kỹ thuật thống nhất do các phẫu thuật viên của 8 bệnh viện đa khoa tuyến tỉnh là Bắc Giang, Bắc Kạn, Cao Bằng, Điện Biên, Hà Giang, Hòa Bình, Sơn La, Tuyên Quang thực hiện.

b. Các chỉ tiêu nghiên cứu. Bệnh nhân được ghi nhận trong bệnh án từ khi vào viện cho đến khi ra viện theo cùng một mẫu bệnh án nghiên cứu. Khám lại sau 3 tháng thông qua khám trực tiếp hoặc qua điện thoại.

\section{Đặc điểm chung}

- Tuổi, giới

- Thời gian bi bênh đến khi được mổ

\section{Triệu chứng lâm sàng}

- Triệu chứng toàn thân VPMRT

- Triệu chứng cơ năng VPMRT

- Triệu chứng thực thể VPMRT

Triệu chứng cận lâm sàng

- Xét nghiệm CTM, CRP

- Siêu âm ổ bụng

- Nuôi cây vi khuẩn

c. Thu thâp thông tin và xử lý số liệu.

Thu thập thông tin. Tất cả các bệnh nhân được thu thập thông tin theo mẫu bệnh án thống nhất gồm toàn bộ các chỉ tiêu nghiên cứu nêu trên. Việc thu thập thông tin do trực tiếp các phẫu thuật viên tham gia phẫu thuật tại 8 Bệnh viện đa khoa tỉnh miền núi: Bắc Giang, Bắc Kạn, Cao Bằng, Điện Biên, Hà Giang, Hòa Bình, Sơn La, Tuyên Quang.

Phương pháp xử lý số liệu

- Các số liệu được xử lý trên máy vi tính bằng phần mềm SPSS 18.

- Sử dụng các test thống kê y học thích hợp

2.3. Đạo đức nghiên cứu. Nghiên cứu được tiến hành thông qua đồng thuận của hội đồng đạo đức viện nghiên cứu 108.

III. KẾT QUẢ NGHIÊN CỨU

Bảng 1. Phân bố bệh nhân theo nhóm tuổi

\begin{tabular}{|c|c|c|}
\hline Tuổi & $\begin{array}{c}\text { Số bệnh nhân } \\
(\mathbf{n = 4 6 8 )}\end{array}$ & Tỷ lệ \% \\
\hline$\leq 18$ & 108 & 23,1 \\
\hline $19-30$ & 95 & 20,3 \\
\hline $31-59$ & 202 & 43,2 \\
\hline$\geq 60$ & 63 & 13,5 \\
\hline Trung bình & \multicolumn{2}{|c|}{$35,90 \pm 20,04(2-87)$} \\
\hline
\end{tabular}

- Phân bố bênh nhân theo giới tính: Nam 48,5\%; Nũ: $51,5 \%$

Bảng 2. Thời gian bệnh nhân đau đến lúc vào viện

\begin{tabular}{|c|c|c|}
\hline $\begin{array}{c}\text { Thời gian } \\
\text { (giờ) }\end{array}$ & $\begin{array}{c}\text { Số bệnh nhân } \\
\text { (n=468) }\end{array}$ & $\begin{array}{c}\text { Tỷ lệ } \\
\text { \% }\end{array}$ \\
\hline Dưới 6 giờ & 15 & 3,2 \\
\hline $6-12$ giờ & 43 & 9,2 \\
\hline$>12-24$ giờ & 103 & 22,0 \\
\hline$>24-48$ giờ & 182 & 38,9 \\
\hline$>48-72$ giờ & 84 & 17,9 \\
\hline >72 giờ & 41 & 8,8 \\
\hline $\begin{array}{c}\text { Trung bình } \pm \text { SD } \\
\text { (min-max) }\end{array}$ & $\begin{array}{c}|c| \\
\text { (n) }\end{array}$ \\
\hline
\end{tabular}

Bảng 3. Vị trí ruột thừa

\begin{tabular}{|c|c|c|}
\hline Vị trí ruột thừa & $\begin{array}{c}\text { Số bệnh } \\
\text { nhẩn } \\
(n=468)\end{array}$ & $\begin{array}{c}\text { Tỷ lệ } \\
\text { \% }\end{array}$ \\
\hline Hố chậu phải & 406 & 86,8 \\
\hline $\begin{array}{l}\text { Hố chậu phải dưới manh } \\
\text { tràng }\end{array}$ & 1 & 0,2 \\
\hline $\begin{array}{c}\text { Hố chậu phải quă̆t sau } \\
\text { manh tràng }\end{array}$ & 7 & 1,5 \\
\hline $\begin{array}{c}\text { Hố chậu phải quă̆t ngược } \\
\text { sau hồi tràng }\end{array}$ & 1 & 0,2 \\
\hline Sau manh tràng & 29 & 6,2 \\
\hline Tiếu khung & 18 & 3,8 \\
\hline Dưới gan & 4 & 0,9 \\
\hline Tiếu khung góc HCP & 1 & 0,2 \\
\hline Dính thành bụng sau bên & 1 & 0,2 \\
\hline
\end{tabular}

Bảng 4. Các nguyên nhân do VRT trên bệnh nhân có nguy cơ cao

\begin{tabular}{|c|c|c|}
\hline Các yếu tố nguy cơ & $\begin{array}{c}\text { Số bệnh nhân } \\
\text { (n=468) }\end{array}$ & $\begin{array}{c}\text { Tỷ lệ } \\
\text { \%o }\end{array}$ \\
\hline $\begin{array}{c}\text { Trình độ học vấn thấp } \\
\text { (mù chữ hoắc chỉ biết } \\
\text { viết) }\end{array}$ & 65 & 13,9 \\
\hline Trẻ em dưới 5 tuổi & 22 & 4,7 \\
\hline Người già $\geq 60$ tuối & 63 & 13,5 \\
\hline Phụ nữ có thai & 4 & 0,9 \\
\hline
\end{tabular}


VIETNAM MEDICAL JOURNAL N²2 - SEPTEMBER - 2021

\begin{tabular}{|c|c|c|c|}
\hline \multicolumn{2}{|c|}{$\begin{array}{c}\text { Phẫu thuâtt lấy thai } \\
\text { từ trước }\end{array}$} & 11 & 2,4 \\
\hline \multicolumn{2}{|c|}{$\begin{array}{c}\text { Phâu thuật ố bụng } \\
\text { khác từ trước }\end{array}$} & 7 & 1,4 \\
\hline \multicolumn{4}{|c|}{ Bảng 5. Triệu chứng toàn thân } \\
\hline \multicolumn{2}{|c|}{ Triệu chứng } & $\begin{array}{c}\text { Số bệnh nhâl } \\
(n=468)\end{array}$ & $\begin{array}{l}\text { Tỉ lệ } \\
(\%)\end{array}$ \\
\hline Tinh thân & Tỉnh táo & 468 & 100 \\
\hline \multirow{3}{*}{ Sốt } & $\begin{array}{l}\text { Không sốt } \\
\left(<37,5^{\circ} \mathrm{C}\right)\end{array}$ & 176 & 37,6 \\
\hline & $\begin{array}{c}\text { Sốt nhe } \\
\left(37,5^{\circ} \mathrm{C}-38^{\circ} \mathrm{C}\right)\end{array}$ & 193 & 41,2 \\
\hline & Sốt cao $\left(>38^{\circ} \mathrm{C}\right)$ & 99 & 21,2 \\
\hline \multicolumn{4}{|c|}{ Bảng 6. Triệu chứng cơ năng } \\
\hline \multicolumn{2}{|c|}{ Triệu chứng } & $\begin{array}{c}\text { Số bệnh } \\
\text { nhẩn } \\
(n=468)\end{array}$ & $\begin{array}{l}\text { Tỉ lệ } \\
(\%)\end{array}$ \\
\hline \multirow{7}{*}{ Vị trí } & $\begin{array}{l}\text { au vùng hố chậu } \\
\text { phải }\end{array}$ & 432 & 92,3 \\
\hline & Đau thượng vị & 50 & 10,7 \\
\hline & au hạ sườn phải & 12 & 2,6 \\
\hline & Đau quanh rốn & 125 & 26,7 \\
\hline & Đau hạ vị & 28 & 6,0 \\
\hline & Hố chậu trái & 2 & 0,4 \\
\hline & Đau nhiều vị trí & 236 & 50,4 \\
\hline \multicolumn{2}{|c|}{ Buồn nôn và nôn } & 146 & 31,2 \\
\hline \multicolumn{2}{|c|}{ Bí trung tiện } & 25 & 5,3 \\
\hline & 3í đại tiện & 30 & 6,4 \\
\hline \multicolumn{4}{|c|}{ Bảng 7. Triệu chứng thực thế } \\
\hline \multicolumn{2}{|c|}{ Triệu chứng } & $\begin{array}{c}\text { Số bệnh } \\
\text { nhẩn } \\
(n=468)\end{array}$ & $\begin{array}{l}\text { Tỉ lê } \\
(\%)\end{array}$ \\
\hline \multirow{3}{*}{$\begin{array}{l}\text { Bưng } \\
\text { chướng }\end{array}$} & Chướng nhiều & 11 & 2,4 \\
\hline & Chướng vừa & 18 & 3,8 \\
\hline & Chướng ít & 132 & 28,2 \\
\hline \multicolumn{2}{|c|}{ Đau hố chậu phải } & 468 & 100,0 \\
\hline \multicolumn{2}{|c|}{ Phản ứng thành bụng HCP } & 468 & 100,0 \\
\hline \multirow{2}{*}{\multicolumn{2}{|c|}{ Cảm ứng phúc mạc }} & 196 & 41,9 \\
\hline & & 5 & 1,1 \\
\hline \multicolumn{2}{|c|}{$\begin{array}{c}\text { Co cứng thành bụng } \\
\text { Sờ thấy khối trong ố bung }\end{array}$} & 11 & 2,4 \\
\hline \multicolumn{2}{|c|}{ Thăm trực tràng có đạu } & 18 & 3,8 \\
\hline
\end{tabular}

Bảng 9. Hình ảnh siêu âm ổ bụng

\begin{tabular}{|c|c|c|c|}
\hline \multicolumn{2}{|c|}{ Hình ảnh siêu âm } & $\begin{array}{c}\text { Số bệnh } \\
\text { nhẩn } \\
(n=468)\end{array}$ & $\begin{array}{l}\text { Tỉ lệ } \\
\text { (\%) }\end{array}$ \\
\hline \multirow{2}{*}{$\begin{array}{l}\text { Dịch ố } \\
\text { bụng }\end{array}$} & Có & 80 & 17,1 \\
\hline & Không & 388 & 82,9 \\
\hline \multirow{3}{*}{$\begin{array}{l}\text { Kích } \\
\text { thước } \\
\text { ruột } \\
\text { thừa }\end{array}$} & Không to & 7 & 1,5 \\
\hline & To & 220 & 47,0 \\
\hline & $\begin{array}{l}\text { Không } \\
\text { thấy }\end{array}$ & 241 & 51,5 \\
\hline \multicolumn{2}{|c|}{ Dày thành RT siêu âm } & 81 & 17,3 \\
\hline \multicolumn{2}{|c|}{ Thâm nhiêm mõ RT } & 214 & 45,7 \\
\hline \multicolumn{2}{|c|}{ Dày thành manh tràng } & 8 & 1,7 \\
\hline \multicolumn{2}{|c|}{ RT võ trên SA } & 1 & 0,2 \\
\hline \multicolumn{2}{|c|}{ Khối khu trú vùng $\mathrm{HCP}$} & 30 & 6,4 \\
\hline \multicolumn{2}{|c|}{ Áp xe RT } & 3 & 0,6 \\
\hline & hân & 17 & 3,6 \\
\hline \multicolumn{4}{|c|}{ Bảng 10. Sốlượng vi khuấn trên/mấu } \\
\hline \multicolumn{2}{|c|}{$N=101(+) / 112$} & $\mathbf{n}$ & $\%$ \\
\hline \multicolumn{2}{|c|}{ Nuôi cấy âm tính } & 11 & 9,8 \\
\hline \multicolumn{2}{|c|}{$1 \mathrm{vk}$} & 97 & 86,6 \\
\hline \multirow{2}{*}{\multicolumn{2}{|c|}{$2 \mathrm{vk}$}} & 3 & 2,7 \\
\hline & & 1 & 0,9 \\
\hline \multicolumn{2}{|c|}{$\geq 3 \mathrm{vk}$} & 112 & 100 \\
\hline
\end{tabular}

Bảng 11. Kêt quả nuôi cấy vi khuẩn

\begin{tabular}{|c|c|c|}
\hline Loại vi khuẩn & $\begin{array}{c}\text { Số bệnh nhân } \\
(\mathbf{n = 1 1 2})\end{array}$ & Tỉ lệ (\%) \\
\hline Ecoli & 82 & 73,2 \\
\hline Klebsiella & 6 & 5,4 \\
\hline Phế câuu & 0 & 0 \\
\hline Acinetobacter & 0 & 0 \\
\hline Pseudomonas & 5 & 4,5 \\
\hline Enterococus & 2 & 1,8 \\
\hline Tụ câuu & 0 & 0 \\
\hline Khác & 11 & 9,8 \\
\hline
\end{tabular}

\section{BÀN LUÂN}

4.1. Tuổi và giới của đối tượng nghiên cứu. Nghiên cứu của chúng tôi bao gồm 468 bênh nhân được PTNS VPMRT tai các viên tỉnh miền núi phía Bắc có độ tuổi trung bình $35,90 \pm$ 20,04 thấp nhất là trẻ em 2 tuổi và cao nhất là 87 tuổi. Độ tuổi 31-60 chiếm tỉ lệ cao nhất $43,2 \%$; đô tuổi $\leq 18$ chiếm tỉ lệ $23,1 \%$; độ tuổi $19-30$ chiếm $20,3 \%$; đồ tuổi $\geq 60$ chiếm tỉ lê thấp nhất $13,5 \%$. Như vậy lứa tuổi hay gặp nhất là trong khoảng 19-60 tuổi chiếm 63,5\%. Đây là lứa tuổi lao động chính của xã hội điều này cho thấy sự ảnh hưởng của VPMRT với năng suất lao động xã hội. Nghiên cứu của chúng tôi cũng thu được tỉ lệ nam nữ gần tương đương nhau: nam chiếm $48,5 \%$; nữ chiếm $51,5 \%$; tỉ lệ nam/nũ 0,94 . Nghiên cứu của chúng tôi cho kết quả tương tự với các tác giả Ndofor, Elhadidi, Gomes 
[1], [2], [3].

Như vậy VPMRT có thể gặp ở mọi lừa tuổi, tuy các thống kê có kết quả khác nhau nhưng đa số các báo cáo đều ghi nhận lứa tuổi 20-60 chiếm tỉ lệ cao nhất. Có sự khác biệt về phân bố giới giữa các nghiên cứu trong khi đa số chỉ ra tỉ lệ gặp VPMRT ở nam cao hơn nhưng nghiên cứu của chúng tôi lại chỉ ra tỉ lệ nam/nữ gần tương đương có thể do đặc trưng vùng miền.

\section{2. Đặc điểm lâm sàng VPMRT}

4.2.1. Thời gian viêm ruôt thừa. Các nghiên cứu trên thế giới chỉ ra bệnh lý VPM RT thường tiến triển sau 24 giờ, nhưng vẩn có một tỉ lệ không nhỏ bệnh nhân VPMRT sớm trước 12 giờ. Do đó chúng tôi phân mốc thời gian dưới 6 giờ; 6-12 giờ, 12-24 giờ, 24-48 giờ, 48-72 giờ, > 72 giờ để cảnh báo VPMRT có thể xảy ra sớm trước 24 giờ và các bác sĩ khám bệnh không nên chủ quan bỏ qua triệu chứng của bệnh nhân. Trong nghiên cứu của chúng tôi Đa số các bênh nhân có thời gian từ khi đau tới lúc được vào viện là trong khoảng 24-48 giờ chiếm 38,9\%; tỉ lệ bệnh nhân đau từ 12-24 giờ chiếm $22,0 \%$; tỉ lể bểnh nhân đau từ 48-72 giờ chiếm 17,9\%; tỉ lệ bệnh nhân đau > 72 giờ chiếm $8,8 \%$; tỉ lệ bệnh nhân đau tới khi vào viện $6-12 \mathrm{~h}$ chiếm $3,2 \%$; tỉ lệ bệnh nhân đau < 6 h thấp chiếm $3,2 \%$. Thời gian đau tới khi được vào viên trung bình là 41,52 giờ. Tỉ lệ VPMRT trước 24 giờ là $34,4 \%$ là một tỉ lệ không nhỏ dễ bị bỏ sót. Kết quả của chúng tôi tương tự với nghiên cứu của tác giả Sheu B.F. (2007) [4].

Như vậy vì nhiêuu lý do khác nhau từ phía $\mathrm{BN}$ cũng như từ thây thuốc mà thời gian từ khi $\mathrm{BN}$ bắt đầu có triệu chứng đau đến khi được phẫu thuật khá dài dẫn tới tăng nguy cơ VPMRT.

\subsubsection{Các yêu tố nguy cơ gây VPMRT}

Vị trí ruột thừa bất thường. Kết quả nghiên cứu của chúng tôi thu được Đa số ruột thừa của bệnh nhân nằm ở vị trí bình thường ở hố chậu phải chiếm $86,8 \%$; có $13,2 \%$ ruột thừa ở vị trí bất thường trong đó sau manh tràng chiếm 6,2\%; trong tiểu khung chiếm 3,8\%; hố chậu phải quặt ngược sau manh tràng chiếm 1,5\%; dưới gan chiếm 0,9\%; hố chậu phải dưới manh tràng hoặc hố chậu phải quặt ngược sau hồi tràng hoặc tiểu khung góc hố chậu phải hoặc dính thành bụng sau bên chiếm $0,2 \%$.

Các yếu tố nguy cơ cao. Trong nghiên cứu của chúng tôi tỉ lệ các yếu tố nguy cớ cao gây VRT trên bệnh nhần bao gồm: trình độ học vấn thấp chiếm $13,9 \%$; trẻ em chiếm 4,7\%; người già chiếm 13,5\%; phụ nữ có thai chiếm $0,9 \%$; phẫu thuật lấy thai từ trước 2,4\%, phẫu thuật ổ bụng khác từ trước 1,4\%.

\subsubsection{Triêu chứng toàn thân VPM RT}

Trong nghiên cứu của chúng tôi khi tiếp nhận các bệnh nhân đều vào viện trong trạng thái tỉnh táo; có $37,6 \%$ bệnh nhân không sốt, tỉ lệ sốt nhẹ chiếm $41,2 \%$ và sốt cao chiếm $21,2 \%$..

4.2.4. Triệu chứng cơ năng VPM RT. Đau bụng là triệu chứng cơ năng cảnh báo trước tất cả các bệnh lý về ổ bụng, các BN thường khởi phát đau ở vùng thượng vị hay cạnh rốn sau đó khu trú ở hố chậu phải. Đau âm ỉ liên tục và tăng dân. Đau có thể giảm đi một thời gian khi RT bị võ (do giảm áp lực trong lòng RT), nhưng ngay sau đó đau sẽ lan tỏa khắp bụng biểu hiện tình trạng VPM- đây là triệu chứng cơ năng thường gặp và dẫn tới việc bệnh nhân phải nhập viện. Khi có tình trạng VPMRT bệnh nhân sẽ có thể xuất hiện các triệu chứng của ứ tắc đường tiêu hóa như nôn, buồn nôn, bí trung, đại tiện, rối loạn tiêu hóa.

Chúng tôi ghi nhận tất cả các bệnh nhân đều có triệu chứng đau bụng trong đó đa số bệnh nhân đau bụng vùng hố chậu phải chiếm $92,3 \%$; đau quanh rốn chiếm 23,7\%; đau thượng vị chiếm 10,7\%; đau hạ vị chiếm 6,0\%; đau hạ sườn phải chiếm $2,6 \%$; đau nhiều vị trí chiếm $50,4 \%$. Tỉ lệ buồn nôn và nôn chiếm $31,2 \%$; tỉ lệ bí trung tiện 5,3\%; tỉ lệ bí đại tiện chiếm 6,4\%.

Kramer (1999) nghiên cứu có $22 \%$ BN bị VRT võ mủ, nhưng có tỉ lệ $31 \%$ cắt RT âm tính ở những $\mathrm{BN}$ có triệu chứng kéo dài $>48$ giờ. Triệu chứng đau dài hớn có ý nghĩa thống kê ở nhóm VRT võ mủ: ở $\mathrm{BN}$ có thời gian đau < 12 giờ chì có $9 \%$ là võ̃ mủ, nhưng tỉ lệ $20 \%$ BN VRT võ có đau 12-24 giờ, tî lệ $25 \%$ BN RT võ có thời gian đau 24-72 giờ và tỉ lệ $22 \%$ BN VRT võ có thời gian đau kéo dài 2-7 ngày [5].

4.2.5. Triệu chứng thực thể của VPM. Nghiên cứu của chúng tôi thu được triệu chứng thực thể thường gặp nhất là đau hố chậu phải, phản ứng thành bụng HCP $100 \%$ ngoài ra còn có Tỉ lệ bệnh nhân có chướng bụng chiếm 34,4\% trong đó $2,4 \%$ bệnh nhân chướng bụng nhiều; $3,8 \%$ bênh nhân chướng bụng vừa và $28,2 \%$ bệnh nhân chướng bụng ít. Tỉ lệ bệnh nhân có đau và phản ứng thành bụng HCP là $100 \%$. Không có bệnh nhân nào tăng cảm giác da vùng HCP. Tỉ lê bênh nhân có cảm ứng phúc mạc là 41,9\%; tỉ lệ bệnh nhân có co cứng thành bụng là $1,1 \%$; có $2,4 \%$ bênh nhân khi thăm khám có sờ thây khối trong ổ bụng; tỉ lệ bệnh nhân được thăm trực tràng có đau chiếm 3,8\%.

Bickell (2005) những yễu tố nguy cơ gây VPMRT là: nam giới, thời gian đau $\geq 36$ giờ, tuối 
$\geq 65$, nhiệt độ cơ thể $\geq 38,9$ độ C [6].

Sheu (2007) ghi nhận những yếu tố nguy cơ dẫn tới VPMRT là: nam giới, sốt $>38$ độ $\mathrm{C}$, suy nhược cơ thể, thời gian khởi bệnh và thời gian nằm theo dõi tai phòng cấp cứu kéo dài, tî lê bạch cầu đa nhẩn trung tính $>76 \%$ và $R T$ nằm ở vị trí sau manh tràng. Dấu hiệu đau lan tỏa, tăng cảm giác ở hố chậu phải gặp ở $86,7 \%$, và cũng chỉ có $75,7 \%$ BN có phản ứng hố chậu phải và tỉ lệ RT nằm sau manh tràng là $18,4 \%$ [4].

Thằm khám lâm sàng vẫn là quyết định chẩn đoán VPMRT tuy nhiên vẫn có những sai khác giữa chẩn đoán trước và sau mổ. Do đó cần có thêm sự trợ giúp từ các phương tiện cận lâm sàng đặc biệt là siêu âm giúp chẩn đoán xác định chính xác.

\subsection{6. Đăc điểm cận lâm sàng}

4.2.6.1. Số lượng bach cầu và $C R P$

Số lương bach cầu. Đặc trưng của VPM RT là tình trạng tăng số lượng bạch cầu thể hiện quá trình viêm cấp hệ thống. Trong nghiên cứu của chúng tôi tỉ lệ tăng bạch câu $\geq 10 \mathrm{G} / \mathrm{L}$ chiếm $79,3 \%$; tỉ lệ hạ bạch cầu $\leq 4 \mathrm{G} / \mathrm{L}$ chiếm $0,4 \%$, tỉ lê bênh nhẩn có bach cầu bình thường 4-10 G/L là $20,3 \%$; tỉ lệ tăng \% bạch câu đa nhân trung tính $\geq 70 \%$ chiếm $88,0 \%$.

Elhadidi (2020) nghiên cứu trên 120 BN VPMRT có số lượng bach cầu trung bình là 16,1 $\pm 1,5 \mathrm{G} / \mathrm{L}$ ở nhóm được PTNS [2].

Như vậy số lượng bạch câu tăng là một dấu hiệu có giá trị giúp chẩn đoán VPMRT. Số lượng bach cầu trong nghiên cứu của chúng tôi tắng cũng phù hợp với nghiên cứu của các tác giả khác.

$\boldsymbol{C R} \boldsymbol{P}$. Trong nghiên cứu của chúng tôi do điều kiện trang thiết bị hạn chế nên chỉ có 48 $(10,2 \%)$ bệnh nhân được làm xét nghiệm CRP trong đó tỉ lệ bệnh nhân có tăng $C R P \geq 5$ chiếm $9,6 \%$.

Tác giả Salem (2007) nhận xét tăng đồng bộ cả CRP và bach cầu $>10 \mathrm{G} / \mathrm{L}$ luôn là dấu hiêu rất có giá trị giúp chẩn đoán các trường hợp VRT có biến chứng [8].

Theo một số tác giả số lượng bach cầu là xét nghiệm có giá trị hớn CRP trong chẩn đoán VRT cấp nhưng ngược lại CRT có giá trị cao hơn trong chẩn đoán các trường hợp VPMRT. Tuy nhiên do số lượng bênh nhân trong nghiên cứu của chúng tôi còn ít nền chưa thể khẳng định chắc chắn vai trò CRP trong chẩn đoán VPMRT.

4.2.6.2. Siêu âm. Trong nghiên cứu này chúng tôi thu thập được dữ kiện siêu âm của tất cả các bệnh nhân cho thấy sự phổ biến của siêu âm tại các tỉnh miền núi phía Bắc trong chẩn đoán VPMRT nói riêng và trong các bệnh lý khác nói chung. Những dấu hiệu trên siêu âm giúp chẩn đoán VPMRT bao gồm: hình ảnh RT bệnh lý, VRT được định hướng chẩn đoán khi xuất hiện hình ảnh cấu trúc hình ống đè không xẹp, cấu trúc này ít di đông trên mặt cắt ngang với thành $R T$ và hình ảnh có dịch trong khoang phúc mạc là rất có giá trị chẩn đoán xác định VPMRT do RT, ngoài ra có thể quan sát hình ảnh khối khu trú, áp xe RT, sỏi phân, tuy nhiên việc chẩn đoán xác định phụ thuộc nhiều vào kinh nghiệm của bác sĩ chẩn đoán hình ảnh cũng như kết hợp với các dữ kiện lâm sàng.

Nghiên cứu của chúng tôi có tỉ lệ bệnh nhân có dịch ổ bụng trên siêu âm là $17,0 \%$; tỉ lệ ruột thừa tăng kích thước quan sát được trên siểu âm là $47,0 \%$; tỉ lệ siêu âm ghi nhận dày thành RT siêu âm $17,3 \%$; thâm nhiễm mỡ RT $45,7 \%$; dày thành manh tràng $1,7 \%$; RT võ trên SA $0,2 \%$; khối khu trú vùng $\mathrm{HCP}$ là $6,4 \%$; áp xe ruột thừa là $0,6 \%$; sỏi phân là $3,6 \%$.

Như vậy siêu âm là phương tiện chẩn đoán hình ảnh được sử dụng nhiều nhất phù hợp với điều kiện vật chất trang thiết bị của các địa phương và kinh tế của $B N$. Chụp CLVT sẽ được sử dụng trong những trường hợp chẩn đoán khó khăn do độ nhay và độ đặc hiệu cao hơn.

4.2.6.3. Đắc điểm vi khuẩn trong mẫu bệnh phẩm và sử dựng kháng sinh

Nghiên cứu của chúng tôi có 112 (23,9\%) bệnh nhân được lấy mẫu cãy vi khuẩn; tỉ lệ cây không mọc là 2,4\%; tỉ lệ mẫu phát hiện vi khuẩn khi nuôi cấy chiếm $21,5 \%$; tỉ lệ phát hiện vi khuẩn E. Coli là 17,5\%; Klebsiella là 1,3\%; Pseudomonas 1,1\%; Enterococus là $0,4 \%$; loại khác $2,4 \%$.

Các trường hợp nuôi cây không mọc có thể do mẫu thực sự không có vi khuẩn hoặc mẫu có vi khuẩn kị khí nhưng nuôi cấy trong môi trường hiếu khí nên không phát hiện được. Do đó chúng tôi thường kết hợp sử dụng kháng sinh nhóm 5nitro-imidazol để kháng chủng kị khí.

\section{KẾT LUÂN}

Việc chẩn đoán chính xác và phát hiện sớm VPMRT tại các tỉnh miền núi phía Bắc đã có nhiều tiến bộ góp phần vào việc ứng dụng phẫu thuật nội soi trong VPMRT để giảm thiểu biến chứng và tăng cường chất lượng sống cho bệnh nhân.

\section{TÀl LIÊU THAM KHẢO}

1. B Ndofor (2016), "Comparing laparoscopic appendectomy to open appendectomy in managing generalised purulent peritonitis from complicated appendicitis: the uncharted path ", S Afr J Surg pp. 30-34.

2. Amro Elhadidi (2020), "Laparoscopicvs open appendectomy in the management of appendicitis complicated by generalized peritonitis: a 
prospective randomized trial", The Egyptian Journal of Surgery, pp. 429-437.

3. Carlos Augusto Gomes (2020), "Laparoscopic versus open approach for diffuse peritonitis from appendicitis ethiology: a subgroup analysis from the Physiological parameters for Prognosis in Abdominal Sepsis (PIPAS) study", Updates in Surgery, pp. 1-7.

4. Sheu B.F. (2007), "Risk factors associated with perforated appendicitis in elderly patients presenting with signs and symptoms of acute appendicitis", ANZ J. Surg., pp. 662-666.
5. Matthias Kraemer (1999), "Perforating Appendicitis: is it a Separate Disease?", Eur J Surg., pp. 473-480.

6. Nina A Bickell (2005), "How Time Affects the Risk of Rupture in Appendicitis", J Am Coll Surg. pp. 401-406.

7. S. Towfigh (2006), "Laparoscopic appendectomy significantly reduces length of stay for perforated appendicitis", Surg Endosc., pp. 495-499.

8. Ta Salem (2007), "Prospective study on the role of C-reactive protein (CRP) in patients with an acute abdomen", Ann R Coll Surg Engl, pp. 233-237.

\section{ĐĂC ĐIỂM HÌNH ẢNH LÂM SÀNG VÀ Cô̂NG HƯỞNG TỪ ĐộNG HỌC SÀN CHÂ̂U Ở BÊ̂NH NHÂN TÁO BÓN DO CO THẮT CO' MU TRỰC TRÀNG (ANISMUS)}

\section{TÓM TẮT}

Mục tiêu: Mô tả các đặc điểm lâm sàng và hình ảnh cổng hưởng từ của bệnh nhân táo bón do co thắt cơ mu trực tràng. Phương pháp nghiên cứu: mô tả cắt ngang từ 7/2020 - 7/2021. Đối tượng nghiên cứu: 30 bệnh nhân được chẩn đoán táo bón do co thắt cơ mu trức tràng được thăm khám lâm sàng và chụp cộng hưởng từ động học sàn chậu tại bệnh viện Đai học Y Hà Nôii. Kết quả: Có 16 nữ, 14 nam đô tuổi trung bình là 46,4士 16,8. Rặn, gắng sức khi đi đại tiện lớn hơn $1 \frac{1}{4}$ số lần là triệu chứng phổ biến nhất với $96,67 \%$. Tỷ lệ triệu chứng phân vón cục lổn nhổn hoặc cứng và cần sự trợ giúp khi đi đại tiện lần lượt là $93.33 \%$ và $86,67 \%$ với điểm Rome IV để đánh giá táo bón trung bình là4,17 $\pm 1,085$. Có sự khác biệt đáng kể về các số đo của góc hậu môn trực tràng (ARA), độ hạ sàn chậu $(\mathrm{M})$, độ mở ống hậu môn, chiều dài $(\mathrm{H})$ và độ dày của cơ mu trực tràng qua các thì nghí, valsava, tống phân phù hợp những đặc điểm của bệnh lý co thắt cơ mu trực tràng. Kết luận: Cộng hưởng từ động học sàn chậuđóng vai trò quan trọng trong chẩn đoán táo bón do co thắt cơ mu trức tràng.

Tư khóa: co thắt cơ mu trực tràng, cộng hưởng từ động học sàn chậu, táo bón, Rome IV

\section{SUMMARY}

CLINICAL FEATURES AND MAGNETIC RESONANCE DEFECOGRAPHY IN PATIENTS

\section{WITH ANISMUS}

Objective: We describeclinical andcharacteristics dynamic MR defecography in patients with anismus. Methods: Describing cross-study from 07/2020 to

${ }^{1}$ Trường Đại học Y Hà Nội

${ }^{2}$ Bênh viên Đai Hoc Y Hà nôi

Chịu trách nhiệm chính: Hoàng Đình Âu

Email: hoangdinhau@gmail.com

Ngày nhận bài: 28.6.2020

Ngày phản biên khoa họ: 20.8.2021

Ngày duyệt bài: 27.8.2021
07/2021. Rearch object: The patient has been clinically diagnosed as constipation becauseanismus, who were indicate magnetic resonance defecographyat Ha Noi Medical University Hospital. Results: This study included 16 females and 14 males; the mean age is $46,4 \pm 16,8$ years old. Straining more than one - fourth $(25 \%)$ of during defecations is the most comon symptom $(96,67 \%)$. The prevalence of lumpy or hard stools and manual maneuvers to facilitate is $93,33 \%$ and $86,67 \%$ with the average Rome IV score for diagnosing constipation is $4,17 \pm 1,085$. There were significant differences in measurements of length $(H)$ and thickness of the puborectalis muscle, anorectal angle (ARA), pelvic floor descent (M), and anal canal opening cross the phases rest, valsava, and defecation and prolonged defecation time were consistent with the features of anismus pathology. Conclusion: constipation becauseanismushas typical sex, age, and MRI features.

Keywords: MR defecography, constipation, Anismus, Rome IV.

\section{I. ĐẶT VẤN ĐỀ}

Táo bón là một vấn đề lâm sàng thường gặp, gây ảnh hưởng đến $20 \%$ dân số [1] có tác động tiêu cực đến chất lượng cuộc sống và gây ra các áp lực về tâm lý đáng kể. Táo bón có nhiều nguyên nhân, tuy nhiên sự phối hợp bất thường dần đến giãn không đầy đủ hoặc co thắt nghịch lý của các cơ vùng sàn chậu là cơ mu trực tràng và cơ thắt hậu môn khi cố gắng tống phẩn trong trực tràng là một nguyên nhân quan trọng [2]. Chẩn đoán táo bón do co thắt cơ mu trực tràng được đưa ra dựa trên lâm sàng với các triệu chứng và thang điểm đánh giá riêng nhưng để xác định chính xác nguyên nhân đôi khi còn gặp khó khăn, cần sự hổ trợ thêm của các phương pháp khác trong đó có chẩn đoán hình ảnh. Chẩn đoán hình ảnh đối với vùng sàn chậu bao 